\section{Re: Psykisk syke lever kortere}

I kronikken Psykisk syke lever kortere i Tidsskriftet nr. 3/2015 (1) skriver Lars Lien og medarbeidere: «Den forventede levetid er omkring 20 år kortere for mennesker med alvorlige psykiske lidelser enn for befolkningen for øvrig. Nesten $60 \%$ av overdødeligheten kan tilskrives somatiske sykdommer med stort potensial for forebygging». Kronikken ble kommentert av Svein Reseland (2). Ved å vise til internasjonal forskning, tillegger han bruken av psykofarmaka en vesentlig årsak til økt dødelighet. Lien har kommentert innlegget og gir avklarende opplysninger. Han sier dette har vært og er under bred debatt. Likeledes at de fleste pasienter i hans omtale ikke hadde vært behandlet med antipsykostiske midler. Den økte dødeligheten var av hjerte- og karsykdommer, diabetes og kreft, dvs. av sykdommer som er relatert til arv og miljø. Det må derfor gjenfinnes biologiske årsaker til dette. Lien fremhever også at det i psykiatrien er behov for økt kompetanse i forebyggende medisin (1).

I Tidsskriftet nr. 15/2015 publiserte Ane Brantzæg Næss og Anna Luise Kirkengen oversiktsartikkelen Er en belastende barndom knyttet til kortere telomerer? (3). Utgangspunktet er at belastning i barndommen, slik som mishandling, omsorgssvikt eller fattigdom, er forbundet med økt sykelighet og dødelighet i voksen alder. De tar utgangspunkt i en fyldig referanseliste hvor kortere teleomerer er funnet.

Hva er telomerer? På alle fire ender av kromosomene sitter DNA-sekvenser som en hette for å beskytte kromosomene mot slitasje. Uten disse vil kromosomene brytes ned og bli ustabile, og cellen vil dø. Det er en signifikant korrelasjon mellom lengden på telomerene og alder, kjønn, dødsrisiko av somatisk sykdom og psykisk sykdom, herav depresjoner og ulike former for stress belastninger (4). Telomerlengden sier noe om forventet levetid, og er også relatert til epigenetiske prosesser som DNA-metylering (5). Epigenetikk er en reversibel endring i genuttrykket som ikke representerer endring i selve genet, men som kan påvirke neste generasjon. Dette omtales i boken Evolution, Early Experience and Human Development, skrevet av Darcia Narvaez og medarbeidere og anmeldt i Tidsskriftet (6). Omsorgssvikt kan derfor merke et barn genetisk.

Kan endret livsstil påvirke genuttrykket og sykdomsrisiko? Utholdenhetstrening spesielt, men også styrketrening har sikre gunstige fysiologiske effekter på de fleste aldringsprosesser, som hjerte- og karsykdommer, diabetes og kanskje demens $(7,8)$. Det er kommet forskningsresultater som finner økt telomerlengde ved fysisk aktivitet $(9,10)$. I en oversiktsartikkel artikkel om epigenetisk regulering av metabolske prosesser indusert av fysisk trening (11), omtaler forfatterne spesifikt effekter på inflammasjon, kreft, sentralnervesystemet, hjerte- og karsystemet og spesielt på telomerlengden som uttrykk for aldring. De konkluderer med at selv om ikke alle data er robuste nok, vil videre forskning sannsynligvis konkludere med at fysisk aktivitet vil ha en essensiell plass i psykisk og somatisk helse i en befolkning.

Den tradisjonelle deling mellom psyke og soma er således utdatert. Kontrollert fysisk kondisjonstrening vil sannsynligvis være et sentralt valg ved mange psykiatriske lidelser. Fysisk og psykisk helse hører nærere sammen enn tidligere antatt.

\section{Tor-Erik Widerøe}

tor-erik.wideroe@ntnu.no

Tor-Erik Widerøe (f. 1940) er professor emeritus ved Institutt for kreftforskning og molekylær medisin, NTNU.

Ingen oppgitte interessekonflikter.

\section{Litteratur}

1. Lien L, Huus G, Morken G. Psykisk syke lever kortere. Tidsskr Nor Legeforen 2015; 135: 246-8

2. Reseland S. Re: Psykisk syke lever kortere. Tidsskr Nor Legeforen 2015; 135 : $1534-5$.

3. Næss AB, Kirkengen AL. Er en belastet barndom knyttet til kortere telomerer? Tidsskr Nor Legeforen 2015; 135: 1356-60.
4. Bojesen SE. Telomeres and human health. J Intern Med 2013; 274: 399-413.

5. Gonzalo S, Jaco I, Fraga MF et al. DNA methyltransferases control telomere length and telomere recombination in mammalian cells. Nat Cell Biol 2006; 8 : 416-24.

6. Vogt H. Nytt lys på mennesket. Tidsskr Nor Legeforen 2013; 133: 1355

7. Gielen S, Schuler G, Adams V. Cardiovascular effects of exercise training: molecular mechanisms. Circulation 2010; 122: 1221-38.

8. Colcombe S, Kramer AF. Fitness effects on the cognitive function of older adults: a meta-analytic study. Psychol Sci 2003; 14: 125-30.

9. Borghini A, Giardini G, Tonacci A et al. Chronic and acute effects of endurance training on telomere length. Mutagenesis 2015; 30: 711-6.

10. Cherkas LF, Hunkin JL, Kato BS et al. The association between physical activity in leisure time and leukocyte telomere length. Arch Intern Med 2008; 168: $154-8$.

11. Ntanasis-Stathopoulos J, Tzanninis J-G, Philippou A et al. Epigenetic regulation on gene expression induced by physical exercise. J Musculoskelet Neuronal Interact 2013; 13: 133-46.

\section{Lien og medarbeidere svarer:}

Takk til Tor-Erik Widerøe for interessante perspektiver på vår artikkel. Vi kjenner lite til telomerforskning, men slik Widerøe beskriver det ser vi at dette kan ha betydning for økt dødelighet i den gruppen vi beskriver. Vi vil tro at telomerene vil ha en viktig rolle særlig knyttet til epigenetikken. Det kan i den sammenheng også være grunn til å trekke fram Forsdahl-Barker hypotesen (1), som sier noe om leveforhold i barneårene og senere dødelighet. Til slutt vil vi takke for påminnelsen om betydningen av fysisk aktivitet. Dette er en bivirkningsfri og godt dokumentert behandling som har effekt både på «psyken og soma».

\section{Lars Lien}

lars.lien@medisin.uio.no

Gitte Huus

Gunnar Morken

Lars Lien (f. 1960) er leder/professor ved Sykehuset Innlandet/Høgskolen i Hedmark.

Ingen oppgitte interessekonflikter.

Gitte Huus (f. 1967) er cand.polit., sosialantropolog og avdelingsdirektør for Avdeling psykisk helsevern og rus i Helsedirektoratet.

Ingen oppgitte interessekonflikter.

Gunnar Morken (f. 1956) er professor i psykiatri ved Norges teknisknaturvitenskapelige universitet, overlege i Divisjon psykisk helsevern, St. Olavs hospital, og avdelingssjef for Avdeling for forskning og utvikling samme sted.

Ingen oppgitte interessekonflikter.

\section{Litteratur}

1. Vangen S, Nordhagen R, Lie KK. Gjensyn med Forsdahl-Barker-hypotesen. Tidsskr Nor Lægeforen 2005; 125: 451-3.

\section{Re: Psykisk syke lever kortere}

Jeg mener at de studiedata som Lars Lien og medarbeidere og TorErik Widerøe viser til, gir en skjev/uriktig fremstilling av psykofarmakas nytteverdi versus skade. Denne skjevheten skyldes bl.a. at det ikke er tatt hensyn til at de ulike dødsårsaksregistrene (som dataene er hentet fra) ikke har den nødvendige kvalitet. Dette problemet er dokumentert i flere artikler/studier, hvor det fremgår at bivirkninger av legemidler som oftest ikke registreres (feilkodes), hvilket medfører at konklusjoner kan være bias $(1,2)$. Dette oppstår når studieforfattere ikke korrigerer for manglende innrapporteringer til de ulike registrene grunnet et redusert antall obduksjoner, uspesifikke eller udefinerte dødsårsaker (f.eks. dødsfall forårsaket av legemiddelforgiftninger) etc.

Som om ikke dette var nok, så overdrives psykofarmakas mulige nytteverdi også i et stort antall av de studier som i utgangspunktet er lagt til grunn for godkjennelsen av legemidlene (3-5). Jeg antar at de ulike lands legemiddelkontroller på et tidlig tidspunkt kunne avslørt at de fleste typer psykofarmaka ikke har en positiv nytte- 